\title{
Simulation of Cr-III dispersion in the High Bogotá River Basin using the WASP model
}

\author{
Simulación mediante el modelo WASP del Cr III en la cuenca alta del río Bogotá
}

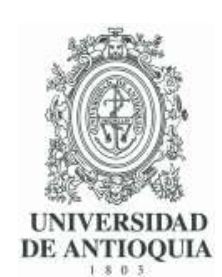

\author{
Luis Ángel Ramos-Ramírez (D) 1, 2*, Marco Andrés Guevara-Luna (D) 1, 3, 4, Juan Sebastián Chiriví-Salomón (iD) 1, 5, 6, Diana \\ Marcela Muñoz-Nieto \\ ${ }^{1}$ Grupo de Conservación, Bioprospección y Desarrollo Sostenible, Escuela de Ciencias Agrícolas, Pecuarias y del Medio Ambiente, \\ Universidad Nacional Abierta y a Distancia. Calle 14 Sur \# 14-23. C. P. 111511. Bogotá, Colombia. \\ ${ }^{2}$ Núcleo Internacional de Pensamiento en Epistemiología Ambiental, Escuela de Ciencias Agrícolas, Pecuarias y del Medio Ambiente, \\ Universidad Nacional Abierta y a Distancia. Calle 14 Sur \# 14-23. C. P. 111511 . Bogotá, Colombia. \\ ${ }^{3}$ Departamento de Ingeniería de Procesos, Smart \& Simple Engineering S.A.S. - S\&SE S.A.S. Calle 65B \# 88-52. C. P. 111071. Bogotá, \\ Colombia. \\ ${ }^{4}$ Grupo de Investigación de Calidad del Aire (GICA), Departamento de Ingeniería Química y Ambiental, Universidad Nacional de Colombia \\ Sede-Bogotá. Carrera 30 \# 45-03. C. P. I 111321. Bogotá, Colombia. \\ ${ }^{5}$ Diseño de Productos y Procesos, Departamento de Ingeniería Química, Universidad de los Andes. Carrera 1 \# 18 ${ }^{\text {a }}$ 12. C. P. 111711. \\ Bogotá, Colombia. \\ ${ }^{6}$ Symbiont Research \& Development Corporation S.A.S. Carrera 2 Este \# 31-56. C. P. 250001. Bogotá, Colombia.
}

\section{CITE THIS ARTICLE AS:}

L. A. Ramos, M. A.

Guevera, J. S. Chiriví and

D. M. Muñoz. "Simulation

of $\mathrm{Cr}$-III dispersion in the

High Bogotá River Basin

using the WASP model",

Revista Facultad de

Ingeniería Universidad de

Antioquia, no. 97, pp.

30-40, Oct-Dec 2020.

[Online]. Available:

https://www.doi.

org/10.17533/udea.

redin. 20191155

\section{ARTICLE INFO:}

Received: July 16, 2019 Accepted: December 10, 2019

Available online:

December 10, 2019

\section{KEYWORDS:}

Water quality modeling; dispersion coefficient; tanning process; water pollution

Modelación de la calidad del agua; coeficiente de dispersión; proceso de curtido; contaminación del agua
ABSTRACT: The Bogotá River is the major river in Cundinamarca and one of the main water streams in the city of Bogotá. Industries from different economic activities have been established around the river, especially tanneries. The current and traditional tanning process requires a large volume of water to be operative, and during their operation environmental problems take place, due to the pollutant discharged in the river with the process water. Chrome III (Cr III) is a persistent pollutant that represents an important public health issue, since it can transform into Chrome $\mathrm{Vl}$, which is very harmful to the environment and people. Water quality simulations were performed for the dispersion of this pollutant in the Bogotá River. The results may help to establish a degree of pollution, monitoring and treatment spots in the river. The main aim of this research is to simulate $\mathrm{Cr}$ III in a defined stretch of $8 \mathrm{~km}$ along from Villapinzón. WASP model was used for the simulations development to represent the $\mathrm{Cr}$ III dispersion at the study conditions. 8 mixing zones were identified in the simulation domain, which constitutes key points for water uptake for treatment and further applications. Additionally, dispersive coefficient, flow, and system geometry were identified as the main factors in the simulation results. Simulation results were validated using IOA as validation parameter between observed and simulated data. A value of 0.853 was obtained for IOA.

RESUMEN: El río Bogotá es el principal en Cundinamarca y una de las corrientes principales de agua en la ciudad de Bogotá. Se establecen diversas industrias alrededor del cuerpo de agua, especialmente curtiembres. El proceso de curtido requiere un gran volumen de agua, durante su operación surgen problemas ambientales relacionados con los vertimientos de las curtiembres. El Cromo III (Cr III) es un contaminante conservativo que representa un importante problema de salud pública, ya que puede transformarse en Cromo VI, siendo este perjudicial para el medio ambiente y la población. Se realizaron simulaciones de calidad del agua para la dispersión de este contaminante en el río Bogotá. Los resultados pueden ayudar a establecer un grado de contaminación, monitoreo y puntos de tratamiento en el río. El objetivo principal de esta investigación es simular el $\mathrm{Cr}$ III en un tramo de $8 \mathrm{~km}$ a lo largo de Villapinzón. Se utilizó el modelo WASP para representar la dispersión de $\mathrm{Cr}$ III bajo las condiciones de estudio. Se identificaron 8 zonas de mezcla en el tramo simulado, siendo estos, puntos clave para implementar medidas de tratamiento y otras aplicaciones. El coeficiente de dispersión, el flujo y la geometría del sistema se identificaron como los principales factores en los resultados de la simulación. La simulación se validó utilizando el IOA como parámetro de validación entre los datos observados y simulados, obteniendo un valor de 0.853 .

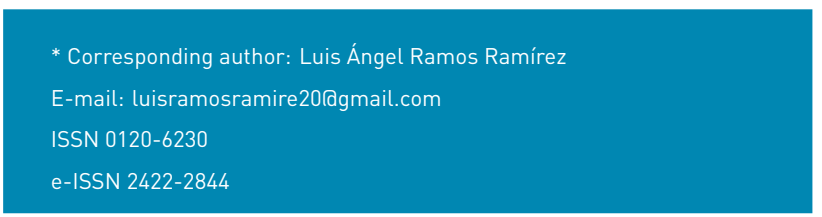




\section{Nomenclature and symbols}

\begin{tabular}{l|l|l}
\hline Symbols & \multicolumn{2}{|c}{ Description } \\
\hline $\mathrm{S}-1 \ldots \mathrm{S}-13$ & \multicolumn{2}{|c}{ Segments } \\
\hline $\mathrm{T}-16, \mathrm{~T}-20$ & \multicolumn{2}{|c}{ Discharges } \\
\hline $\mathrm{D}-1 \ldots \mathrm{D}-7$ & \multicolumn{2}{|c}{ Description } \\
\hline Symbol & Units & Punctual concentration \\
\hline $\mathrm{c}$ & $\mu \mathrm{g} / \mathrm{L}$ & Longitudinal speed \\
\hline $\mathrm{u}$ & $\mathrm{m} / \mathrm{s}$ & Lateral speed \\
\hline $\mathrm{V}$ & $\mathrm{m} / \mathrm{s}$ & Vertical speed \\
\hline $\mathrm{W}$ & $\mathrm{m} / \mathrm{s}$ & $\begin{array}{l}\text { Longitudinal diffusion } \\
\text { coefficient }\end{array}$ \\
\hline$E_{x}$ & $\mathrm{~m}^{2} / \mathrm{s}$ & $\begin{array}{l}\text { Lateral diffusion } \\
\text { coefficient }\end{array}$ \\
\hline$E_{y}$ & $\mathrm{~m}^{2} / \mathrm{s}$ & $\begin{array}{l}\text { Vertical diffusion } \\
\text { coefficient }\end{array}$ \\
\hline$E_{z}$ & $\mathrm{~m}^{2} / \mathrm{s}$ & $\begin{array}{l}\text { Average speed of } \\
\text { the stream }\end{array}$ \\
\hline$U$ & $\mathrm{~m} / \mathrm{s}$ & Section width \\
\hline$B$ & $\mathrm{~m}$ & Hydraulic radius \\
\hline$D$ & $\mathrm{~m}^{2}$ & cutting speed \\
\hline$u^{*}$ & $\mathrm{~m} / \mathrm{s}$ & Flow \\
\hline$Q$ & $\mathrm{~m}^{3} / \mathrm{s}$ & Wet area \\
\hline$A$ & $\mathrm{~m}^{2}$ & Wet perimeter \\
\hline$p$ & $\mathrm{~m}$ & Hydraulic ratio \\
\hline$R$ & $\mathrm{~m}$ & Peclet number \\
\hline$P_{e}$ & Dimensionless & $\begin{array}{l}\text { Courant number for } \\
\text { advective flow }\end{array}$ \\
\hline$C_{a}$ & Dimensionless \\
\hline$C_{d}$ & Dimensionless & $\begin{array}{l}\text { Courant number for } \\
\text { dispersive flow }\end{array}$ \\
\hline & & \\
\hline
\end{tabular}

\section{Introduction}

The Bogotá River Basin has a total area of $276.2 \mathrm{~km}^{2}$, which is constituted by a unimodal rainfall regimen between April and October. Along its route, ecosystems such as Andean Woods resulted being vulnerable due to water contamination. There is a compelling need to recover and to conserve this resource [1]. Tanneries are industries belonging to a traditional economic activity in Cundinamarca - Colombia, where animal raw hides are transformed in leather. According to the POT (Plan de Ordenamiento Territorial), up to 131 tanneries have been established around the riverside from 1,820 to 2,000. Most of them came from Villapinzón, Cundinamarca. Nevertheless, the number of small tanning companies started to decrease from 2001 because of closes and sanctions performed by the Corporación Autónoma Regional (CAR), which monitors and regulates environmental policies of their discharges [2].

\begin{tabular}{|c|c|c|}
\hline Units & Magnitude & Description \\
\hline g & Gram & \multirow{3}{*}{ Mass } \\
\hline Metric Ton & Ton & \\
\hline$\mu \mathrm{g}$ & Microgram & \\
\hline $\mathrm{m}$ & Meter & Length \\
\hline$m^{2}$ & Square meter & \multirow{2}{*}{ Area } \\
\hline ha & Hectare & \\
\hline $\mathrm{mm}$ & Millimeter & \multirow{3}{*}{ Volume } \\
\hline $\mathrm{L}$ & Liter & \\
\hline $\mathrm{m}^{3}$ & Cubic Meter & \\
\hline $\mathrm{h}$ & Hour & \multirow{4}{*}{ Time } \\
\hline s & Second & \\
\hline day & Day & \\
\hline $\min$ & Minutes & \\
\hline$\mu \mathrm{g} / \mathrm{L}$ & Microgram per liter & \multirow{2}{*}{ Mass concentration } \\
\hline$\mu \mathrm{g} \mathrm{Cr} / \mathrm{L}$ & $\begin{array}{l}\text { Microgram of Chrome } \\
\text { per liter }\end{array}$ & \\
\hline $\mathrm{m} / \mathrm{s}$ & Meter per second & Velocity \\
\hline $\mathrm{m}^{3} / \mathrm{h}$ & Cubic meter per hour & \multirow{2}{*}{ Volumetric flow } \\
\hline $\mathrm{m}^{3} / \mathrm{s}$ & Cubic meter per second & \\
\hline $\mathrm{m}^{2} / \mathrm{s}$ & Square meter per second & Viscosity \\
\hline $\mathrm{g} /\left(\mathrm{m}^{3}\right.$ day $)$ & $\begin{array}{l}\text { Grams per cubic meter } \\
\text { per day }\end{array}$ & $\begin{array}{l}\text { Direct and diffuse } \\
\text { charge rate }\end{array}$ \\
\hline $\mathrm{m}$ asl & Meters above sea level & Height \\
\hline
\end{tabular}

Water harvesting and discharges made by tanneries in the High Bogotá River Basin have been invariant due to the significant volume needed by these industries, which is approximately to $12.30 \mathrm{~m}^{3} / \mathrm{t}$ [2]. According to Observatorio Regional Ambiental y de Desarrollo Sostenible del Río Bogotá (Orarbo), the High Bogotá River Basin has a good water quality index (0.90) in upstream of Villapinzón and regular index (0.37) in downstream of Chocontá [3]. However, the main issues are that $\mathrm{Cr}$ III composes these discharges and there is an absence of adequate treatment by $98 \%$ of the industry, which are conformed mainly by small companies $[4,5]$. The risk that hosts a high concentration of $\mathrm{Cr}$ III in the water is because it can react to $\mathrm{Cr} \mathrm{Vl}$, which is highly harmful and is classified as a carcinogenic substance [4]. This situation in public health is important and trends to be economically important; thus, regulations and management should be implemented [5].

Simulation of persistent pollutants in Colombia has not a broad background. Preview studies are restricted to water bodies in high mountains, and only few have been developed. The software Water Quality Analysis Simulation Program (WASP) 7.0, promoted by US Environmental Protection Agency, predicts and performs simulations of water quality in response to natural phenomena and human-induced pollution. Nevertheless, this program has not yet been applied in Colombia. Simulations in the Suquiapa River in El Salvador and Tibacay River in 
Ecuador demonstrate an accurate adaptation of WASP to segments, hydraulic variables, and boundary conditions from water bodies in high mountains, such as High Bogotá River Basin $[6,7]$ WASP includes submodules which allow studying different compounds, such as the simulation of Cr III through simple toxicant submodule [8].

This study focuses on the simulation of $\mathrm{Cr}$ III, which is a persistent pollutant and a non-biodegradable mineral harmful for human and animal health. Hydrologic dynamics of $\mathrm{Cr}$ III provides monitoring and control strategies for sanity and environmental impact reduction of heavy metals. This simulation in the High Bogotá River Basin affords to understand changes in $\mathrm{Cr}$ III according to spatial and temporary factors. Therefore, the aim of this research was to elucidate these changes along this water body via WASP simulation. An initial validation was developed by both pollutant load error and continuity of water volume error. A quantitative validation of the $\mathrm{Cr}$ III concentrations was performed using the Index of Agreement (IOA) validation parameter.

\section{Materials and methods}

\subsection{Delimitation and characterization of the study zone}

This research was developed for the High Bogotá River Basin, which is located in the north-eastern sector of the Department of Cundinamarca (Figure 1). 13 segments, 7 tanneries and 2 streams of discharge were assigned (Figure 2). Values of water level were extracted from level control and CAR monitoring stations from El Triunfo and Villapinzón.

The High Bogotá River Basin is constituted by the municipalities of Suesca, Lenguazaque, Machetá, Villapinzóm, and Chocontá. In 1,982, the source of the Bogotá River was declared a forest reserve zone, reaching 1,128 ha. Its headwaters are located about 3,450 $\mathrm{m}$ asl in the wasteland Guacheneque in Villapinzón, and its mouth is about $2,600 \mathrm{~m}$ asl in the Sisga River. The median annual precipitation is $850 \mathrm{~mm}$, being July and January the rainiest and driest months respectively. The average annual relative humidity has a similar behavior of the precipitation, following a monomodal regime. The highest relative humidity values were registered between April and September, with July being the wettest month with a value of $91 \%$ [1].

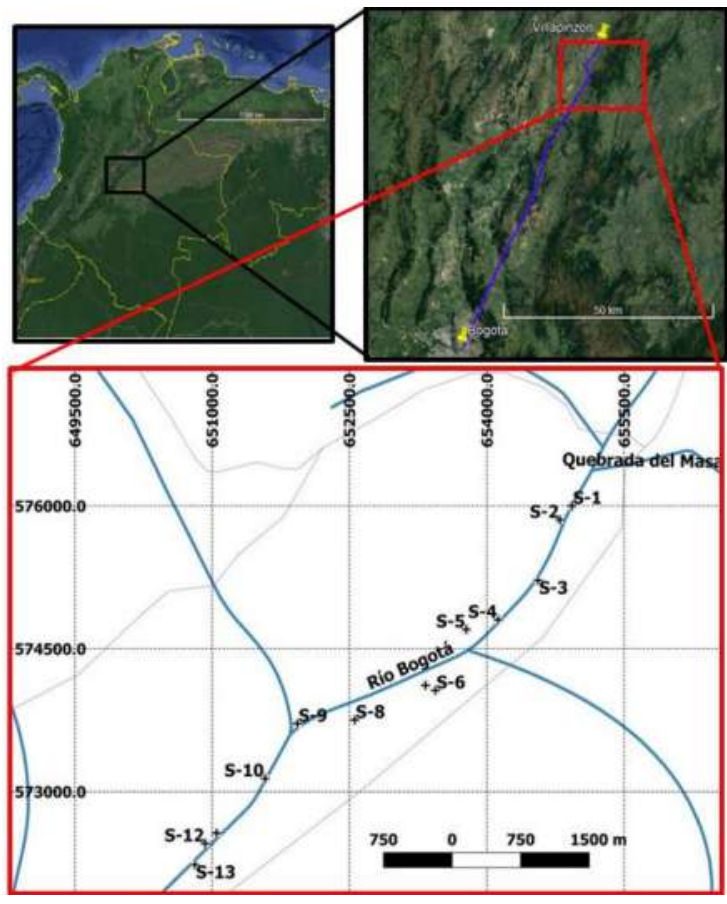

Figure 1 Location of the study zone: The High Bogotá River Basin

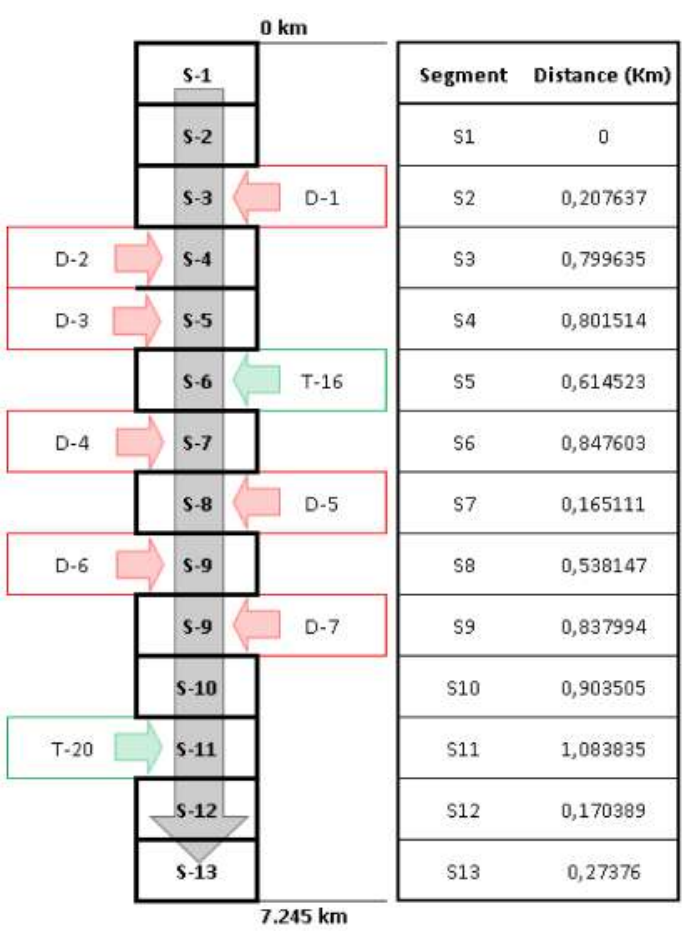

Figure 2 Segments and discharges in the simulated stretch of the river

\subsection{Selection of Water Quality Analysis Simulation Program (WASP)}

In this study, WASP $\AA$ was chosen to model the contamination of $\mathrm{Cr}$ III in the High Bogotá River Basin. 
This selection was based on the comparison of license type (commercial or free), model type, water body admitted, and the phenomenological variables included of available programs. According to previous studies in rivers with similar characteristics [8, 9], the user-friendliness on the interface, and the simulation scope for conservative pollutants were selected as essential factors in this study case. Also, its easiness to install in any computer made the selection easier and remarkable for future investigations.

\subsection{Model and equations}

A partial differential equation based on the law of mass conservation was formulated including terms that describe the pollutant transport, inputs and outputs of the system, variables related with hydraulics conditions, diffuse discharges, punctual discharges, and the analyte capacity (Equation 1). This equation presents the continuity of the fluid in a Cartesian coordinate 3D system and make reference to the lateral $(x)$, longitudinal $(y)$ and vertical $(z)$ transport, which can be produced by the mechanisms of advection $(u c, v c$, and $w d)$, diffusion $(E)$, loads direct or diffuse $\left(S_{L}\right)$, exchange of matter with sediments $\left(S_{B}\right)$, or kinetic transformations $\left(S_{k}\right)$.

$$
\begin{aligned}
& \frac{\partial c}{\partial t}= \frac{\partial}{\partial x}(u c)-\frac{\partial}{\partial y}(v c)-\frac{\partial}{\partial z}(w d)+ \\
& \frac{\partial}{\partial x}\left(E_{x} \frac{\partial c}{\partial x}\right)+\frac{\partial}{\partial y}\left(E_{y} \frac{\partial c}{\partial y}\right)+ \frac{\partial}{\partial z}\left(E_{z} \frac{\partial c}{\partial z}\right)+ \\
& S_{L}+S_{B}+S_{K}
\end{aligned}
$$

An equation was developed from variables associated with $X$-axis and time $(t)$ (Equation 2, Table 1). This equation resulted from the suppression of the terms related to $Y$ and Z-axis, which comes from a vertical and horizontal homogeneity assumption in each segment [9] WASP ${ }^{\circ}$ applies a numerical approximation using finite differences, with centered numeric derivatives, in first-order Eulerian scheme, for the solving of the mentioned equations [9]. This numerical approach is based on an Euler method for Ordinary Differential Equations (ODE). This approach is numerically implicit and is the basis for the finite differences scheme used by the model.

$$
\begin{array}{r}
\frac{\partial}{\partial t}(A C)=\frac{\partial}{\partial x}\left(-U_{x} A C+E_{x} A \frac{\partial c}{\partial x}\right)+ \\
A\left(S_{L}+S_{B}\right)+A\left(S_{k}\right)
\end{array}
$$

The pollutant transport in a water body is dependent on the dispersion coefficient $\left(E_{t}\right)$. According to Barchiesi and co-authors (2015), the Fischer equation (Equation 3) provides the best estimation for the current study case [11].

$$
E_{x}=\frac{0.011 * U^{2} * B^{2}}{D * u^{*}}
$$

Flows were determined from the Manning equation (Equation 4). Variables such as the geometry of the section (Figure 3), the wet area (Equation 5), the wet perimeter (Equation 6), and the hydraulic ratio (Equation 7) were taken from Villapinzón-2120815 limnometric station and the classification proposed by other authors (Table 2) [12].

$$
Q=\frac{A * S^{\frac{1}{2}} * R^{\frac{2}{3}}}{n}
$$

$$
A=\frac{2}{3} T y
$$

$$
\begin{gathered}
p=T+\frac{8 * y^{2}}{3 * T} \\
R=\frac{A}{p}
\end{gathered}
$$

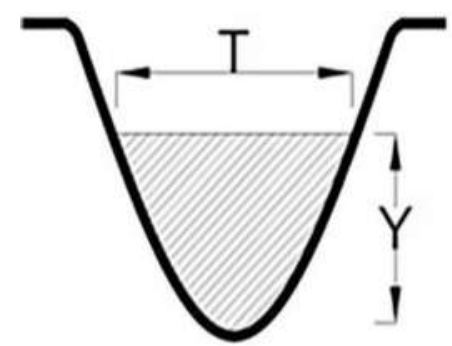

Figure 3 Geometry of the river section assumed by the mathematical model

The parabolic sections scheme shown in Figure 3 was used to model the system based on Equation 5, 6, and 7. This geometry section is based on the Schumm classification [13].

The Peclet number was calculated (Equation 8) [14], and the dominating mechanism was determined in the water body taking account guidelines from other studies $[15,16]$ criteria. These criteria established that an advective runoff trends to present an infinite Peclet' number and advective dominates over diffusion starts when $P_{e}>1$. Therefore, a highly convective flow was identified in the studied system.

$$
P_{e}=\frac{C_{a}}{C_{d}} \rightarrow \quad C_{a}=\frac{U * \Delta t}{\Delta x} ; C_{d}=\frac{D \Delta t}{\Delta x^{2}}
$$

\subsection{Discharges concentration}

The concentration of the discharges was determined from the stochiometric adjustment of the chemical reaction of $\mathrm{Cr}$ in the tanning process.

$$
\begin{aligned}
& 8 \mathrm{Na}_{2} \mathrm{Cr}_{2}^{+6} \mathrm{O}_{7}+32 \mathrm{H}_{2} \mathrm{SO}_{4}+\mathrm{C}_{12} \mathrm{H}_{22} \mathrm{O}_{11} \rightarrow \\
& 8 \mathrm{Na}_{2} \mathrm{SO}_{4}+8 \mathrm{Cr}_{2}^{+3}\left(\mathrm{SO}_{4}\right)_{3}+43 \mathrm{H}_{2} \mathrm{O}+12 \mathrm{CO}_{2}
\end{aligned}
$$


Table 1 Hydraulic variables associated with the central equation of the system

\begin{tabular}{|c|c|c|}
\hline Variable & Unit & Description \\
\hline$C:$ constituent concentration & $\mu \mathrm{g} / \mathrm{L}$ & $\begin{array}{l}\text { The } \mathrm{Cr} \text { concentration of main } \\
\text { segments and streams that was } \\
\text { taken from backgrounds about } \\
\text { the study zone [10]. A mass } \\
\text { balance of the tanning process } \\
\text { was made for discharges. }\end{array}$ \\
\hline $\boldsymbol{A}:$ Cross-surface section to the flow & $m^{2}$ & $\begin{array}{l}\text { The wet area was determined } \\
\text { according to the geometry of } \\
\text { sections of each segment }\end{array}$ \\
\hline$U_{\boldsymbol{x}}$ : mean longitudinal velocity & $\mathrm{m} / \mathrm{s}$ & $\begin{array}{l}\text { The flow of each segment was } \\
\text { divided per its corresponding } \\
\text { area. }\end{array}$ \\
\hline $\boldsymbol{E}_{\boldsymbol{x}}$ : longitudinal dispersion coefficient & $\mathrm{m}^{2} / \mathrm{s}$ & $\begin{array}{l}\text { This variable was determined } \\
\text { by applying the Fischer } \\
\text { equation and the Peclet number. }\end{array}$ \\
\hline$S_{L}:$ Direct and diffuse charge rate & \multirow[b]{2}{*}{$\mathrm{g} /\left(\mathrm{m}^{3}\right.$ day $)$} & \multirow{2}{*}{$\begin{array}{l}\text { These variables are included in } \\
\text { the mathematical model used } \\
\text { by WASP to consider the } \\
\text { pollutant dispersion. }\end{array}$} \\
\hline $\begin{array}{l}S_{B}: \text { Contour charge rate } \\
S_{K}: \begin{array}{l}\text { Total kinetic transformation } \\
\text { rate }\end{array}\end{array}$ & & \\
\hline
\end{tabular}

Table 2 Classification of streams according to Schumm [13]

\begin{tabular}{llll}
\hline $\begin{array}{l}\text { Sediment } \\
\text { transport }\end{array}$ & \multicolumn{2}{c}{ Stability of stream } \\
\cline { 2 - 4 } $\begin{array}{l}\text { 85-100\% in the } \\
\text { suspension }\end{array}$ & $\begin{array}{l}\mathrm{P}>2.1 \\
\mathrm{~S}: \text { low }\end{array}$ & $\begin{array}{l}\text { The main deposit occurs on the banks } \\
\text { when narrowing of stream starts. The } \\
\text { sediment in the bottom of the river is } \\
\text { slight. }\end{array}$ & $\begin{array}{l}\text { Erosion in the bottom dominates in } \\
\text { the system. Enlargement on the } \\
\text { banks is low. }\end{array}$ \\
\hline $\begin{array}{l}\text { 65-85\% in the } \\
\text { suspension and 15-35 } \\
\text { on the banks. }\end{array}$ & $\begin{array}{l}\mathrm{P}<2.1 \\
\mathrm{~S}: \text { moderated }\end{array}$ & $\begin{array}{l}\text { Deposit occurs in both banks and } \\
\text { bottom of the river. }\end{array}$ & $\begin{array}{l}\text { Both erosion in the bottom and the } \\
\text { enlargement on the banks are } \\
\text { critical. }\end{array}$ \\
\hline $\begin{array}{l}\text { 35-70\% on the } \\
\text { banks. }\end{array}$ & $\begin{array}{l}1<\mathrm{P}<1.5 \\
\mathrm{~S}: \text { high }\end{array}$ & $\begin{array}{l}\text { The sediment in the bottom is high } \\
\text { and formation of islands is observed. }\end{array}$ & $\begin{array}{l}\text { Enlargement on the banks } \\
\text { dominates the system. Erosion in } \\
\text { the bottom is low }\end{array}$ \\
\hline
\end{tabular}

${ }^{*}$ P: Sinuosity, S: Slope

From the balanced reaction (Equation 9), the concentration of $\mathrm{Cr}$ III in the discharges from the tanneries was estimated from the mass percentage of $\mathrm{Cr}$ in the products, the water consumption reported in the balance performed by US EPA in 2006 [15], and the number of processed hides [16]. The output flowrate of the tanning process is $2.36111 \times 10^{-6}$ $\mathrm{m}^{3} / \mathrm{s}$ of process water, $0.221 \mathrm{~kg}$ of chromium sulfate are commonly used, with this data and the mass percentage of $\mathrm{Cr}$ III (3.32\%) present in the used salt during the production process, the concentration of $\mathrm{Cr}$ III in the stream is obtained (6890000 $\mu \mathrm{g} \mathrm{Cr} / L$ ) [17] .

\subsection{Validation}

The error percentage in the simulation was determined by the calculation of continuity error for the water volume and pollutant in the segments in the simulated stretch. The continuity error in the volume corresponds to the difference in the initial water mass in the simulated stretch (S-1) with the sum of the flows in the inputs from the system (D-1 to D-7), including the value of flow in the final segment (S-13) and San Pedro' and Chingacio' streams (T-16 and T-20, respectively) (Equation 10). The error of the pollutant charge in the mass of the system was calculated based on the concentration of $\mathrm{Cr}$ in the system' discharges which was an input to the model (Equation 11). Chrome prediction results at the end of each segment were subtracted from the concentration of the discharges, and then, divided by obtained value in the simulation. The Index of Agreement (IOA $>0.6)$ was applied to evaluate the performance of the model [18]. Equation 10 to 13 illustrate the error calculation and validation parameters 
considered for the model performance validation.

The data used for the validation consists in the observed and simulated $\mathrm{Cr}$ III concentration (Equation 11), data used is available through the link in the supplementary material of this article.

$$
\text { Error }_{1}=\sum \mathrm{Q}_{\text {segment }}(\mathrm{V}-1, \mathrm{~T}-13, \mathrm{~T}-16 . \mathrm{T}-20)-\mathrm{Q}_{\mathrm{T}-1}
$$

Observed concentration $=$

$$
\frac{\text { Discharge concentration } * Q \text { discharge }}{Q \text { segment }}
$$

Error $_{2}=$

Input concentration - Simulated concentration Simulated concentration

$$
\mathrm{IOA}=1-\frac{\sum_{\mathrm{i}=1}^{\mathrm{n}}\left(\mathrm{O}_{\mathrm{i}}-\mathrm{P}_{\mathrm{i}}\right)^{2}}{\sum_{\mathrm{i}=1}^{\mathrm{n}}\left(\left|\mathrm{P}_{\mathrm{i}}-\overline{\mathrm{O}}\right|+\left|\mathrm{O}_{\mathrm{i}}-\overline{\mathrm{O}}\right|\right)^{2}}
$$

\subsection{Application of WASP and configuration of the model}

The simulation was developed using WASP model $v 7.0$ [19]. The simulation was performed on a computer with 6 GB RAM, Windows 10 as the operating system, and Intel Core i5 - 5500U. The model set-up was based on the Net flow option, this option assumes one single flow direction for the water in the simulated systems [19]. Euler method was selected as numerical solution method, it allows solving ODE along the segments distance considering specific initial and boundary conditions [20]. Additionally, the Euler method presents a fast and good convergence. The simulation execution time was 24 hours using this numerical approach.

The sub-model simple toxicant was chosen for the system physics representation since it has affinity for metal compounds modeling, among other pollutants [6]. Depth, width, length, $\mathrm{Cr}$ concentration, and segment type were provided to WASP as input information for the simulation. The volume and characterization of each segment were based on the measured data collected data.

Advective and dispersive factors were defined as follow: advective transport were established by entering the flow values at the initial state of each segment allowing to represent the flows associated with the water streams inside the simulated system. Dispersive factor was determined based on the cross and longitudinal dimensions. The post-processing module of WASP allowed to export and analyze concentration changes of the $\mathrm{Cr}$ III at spatial and temporal scales (Figure 4).

\section{Results and discussion}

The concentration of $\mathrm{Cr}$ III and flow values associated with discharges points (Table 3) were obtained from the empirical equations and experimental data [15]. The concentration used in Equation 11 was calculated by multiplying flows and concentrations of discharges. The error percentage for pollutant load was minimum with the model implemented, and accurate results were obtained based on the relation between the simulated and observed concentration. An invariant pollutant load was calculated based on the assumption that all discharges have a $\mathrm{Cr}$-III-rich tanning origin. Pollutant load values are agreed with observed pollutant concentration $16890000 \mu \mathrm{g} \mathrm{Cr} / \mathrm{L}$, 2,36111 E-06 $\mathrm{m}^{3} / \mathrm{s}$ ) [15].

Figure 5 shows the observed and simulated $\mathrm{Cr}$ concentration profiles, the water flowrate profile and the punctual percentage of error is reported. The errors computed are in a range between $0.14 \%$ and $39.26 \%$. A correspondence in terms of trend for the observed and simulated $\mathrm{Cr}$ concentrations is evidenced, even so, the simulated $\mathrm{Cr}$ concentrations are more sensitive to changes in the water flowrates. By example in S-9 a decrease in the flowrates of water is registered, but by comparing the $\mathrm{Cr}$ concentrations the simulated profile shows a peak of higher Value meanwhile the observed $\mathrm{Cr}$ concentration does not change strongly.

From Figure 5, it is possible to observe in sections S-6, S-7, S-8, S-10, S-11 and S-12 a good correspondence between the simulated and observed $\mathrm{Cr}$ concentration profiles. These sections of the river correspond to a small change in water flowrates.

Mixing zones were identified in each segment from the stretch. These zones represent the maximum possible dilution of $\mathrm{Cr}$ III in the water flowrate. Mixing zones also avoid fluctuations in the pollutant concentration. Mixing zones are constituted mainly by 2 steps: turbulence zone and far field zone. Turbulence zone is where the discharge is added, and the Far field zone is where changes in the pollutant only depend on the hydraulic phenomena. From the simulation, initial, minimal, and maximum concentrations of $\mathrm{Cr}$ were obtained as results (Figure 5 and 6).

A progressive increase of $\mathrm{Cr}$ concentration was observed in the relation of time until achieving the mixing condition in the system. From this behavior, an interruption was detected in S-6 were initial concentration, and the mixing zone reached values of $44,38 \mu \mathrm{g} / \mathrm{L}$ and $27,74 \mu \mathrm{g} / \mathrm{L}$, respectively. This result is more likely due to the inlet of a stream (D-16) of $0.499 \mathrm{~m}^{3} / \mathrm{s}$ clean of $\mathrm{Cr}$. This input dilutes $\mathrm{Cr}$ because the available water volume is greater. This 


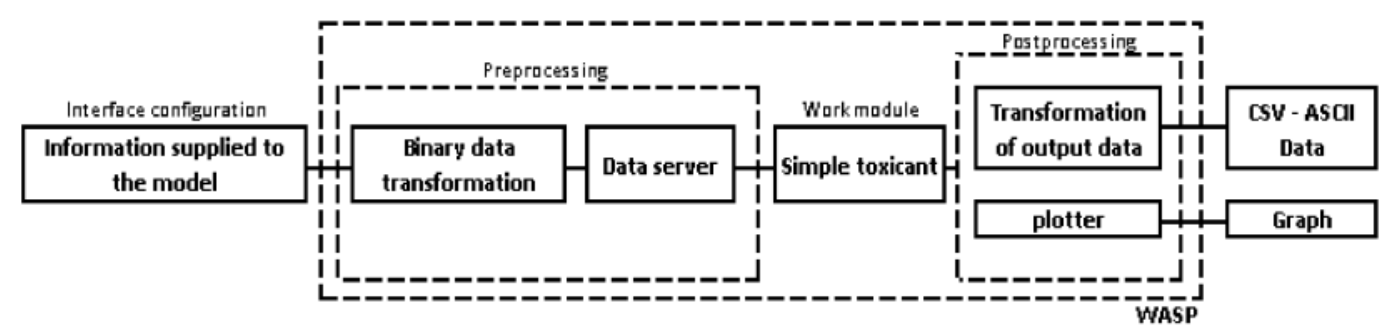

Figure 4 WASP model information structure

Table 3 Concentrations and time where a maximum dilution (mixing condition) of $\mathrm{Cr}$ concentration was achieved

\begin{tabular}{lllll}
\hline \multirow{2}{*}{ Segment } & $\begin{array}{l}\text { Initial concentration } \\
\boldsymbol{\mu} \mathbf{g} / \mathbf{L}\end{array}$ & $\begin{array}{l}\text { Maximum concentration } \\
\boldsymbol{\mu} \mathbf{g} / \mathbf{L}\end{array}$ & $\begin{array}{l}\text { Minimal concentration } \\
\boldsymbol{\mu} \mathbf{g} / \mathbf{L}\end{array}$ & $\begin{array}{l}\text { Concentration in the mix zone } \\
\boldsymbol{\mu g} / \mathbf{L}\end{array}$ \\
\hline $\mathrm{S}-2$ & $0(0: 00: 00 \mathrm{~h})$ & $0.02(2: 24: 08 \mathrm{~h})$ & $0(0: 00: 00 \mathrm{~h})$ & $0.02(2: 24: 08 \mathrm{~h})$ \\
$\mathrm{S}-3$ & $0(0: 00: 00 \mathrm{~h})$ & $12.9(4: 48: 08 \mathrm{~h})$ & $0(0: 00: 00 \mathrm{~h})$ & $12.9(4: 48: 08 \mathrm{~h})$ \\
$\mathrm{S}-4$ & $0(0: 00: 00 \mathrm{~h})$ & $25.78(2: 24: 00 \mathrm{~h})$ & $0(0: 00: 00 \mathrm{~h})$ & $25.78(7: 12: 08 \mathrm{~h})$ \\
$\mathrm{S}-5$ & $11.06(0: 00: 00 \mathrm{~h})$ & $38.63(12: 00: 00 \mathrm{~h})$ & $11.06(0: 00: 00 \mathrm{~h})$ & $38.63(12: 00: 00 \mathrm{~h})$ \\
$\mathrm{S}-6$ & $44.38(0: 00: 00 \mathrm{~h})$ & $44.38(0: 00: 00 \mathrm{~h})$ & $19.66(2: 24: 08 \mathrm{~h})$ & $27.74(14: 24: 08 \mathrm{~h})$ \\
$\mathrm{S}-7$ & $88.0(0: 00: 00 \mathrm{~h})$ & $88.0(0: 00: 00 \mathrm{~h})$ & $33.46(4: 48: 08 \mathrm{~h})$ & $36.94(14: 24: 08 \mathrm{~h})$ \\
$\mathrm{S}-8$ & $1,739.0(0: 00: 00 \mathrm{~h})$ & $1,739.0(0: 00: 00 \mathrm{~h})$ & $46.12(12: 00: 00 \mathrm{~h})$ & $46.18(16: 48: 00 \mathrm{~h})$ \\
$\mathrm{S}-9$ & $59.68(0: 00: 00 \mathrm{~h})$ & $528.72(2: 24: 08 \mathrm{~h})$ & $59.68(0: 00: 00 \mathrm{~h})$ & $64.63(21: 36: 08 \mathrm{~h})$ \\
$\mathrm{S}-10$ & $446.0(0: 00: 00 \mathrm{~h})$ & $506.98(2: 24: 08 \mathrm{~h})$ & $64.78(0: 00: 08 \mathrm{~h})$ & Not reached \\
$\mathrm{S}-11$ & $1,265.0(0: 00: 00 \mathrm{~h})$ & $1,265.0(0: 00: 00 \mathrm{~h})$ & $65.33(0: 00: 08 \mathrm{~h})$ & Not reached \\
$\mathrm{S}-12$ & $1,112.0(0: 00: 00 \mathrm{~h})$ & $1,112.15(0: 00: 08 \mathrm{~h})$ & $69.4(0: 00: 08 \mathrm{~h})$ & Not reached \\
$\mathrm{S}-13$ & $959.0(0: 00: 00 \mathrm{~h})$ & $1,017.4(2: 24: 00 \mathrm{~h})$ & $82.39(0: 00: 08 \mathrm{~h})$ & Not reached \\
\hline
\end{tabular}

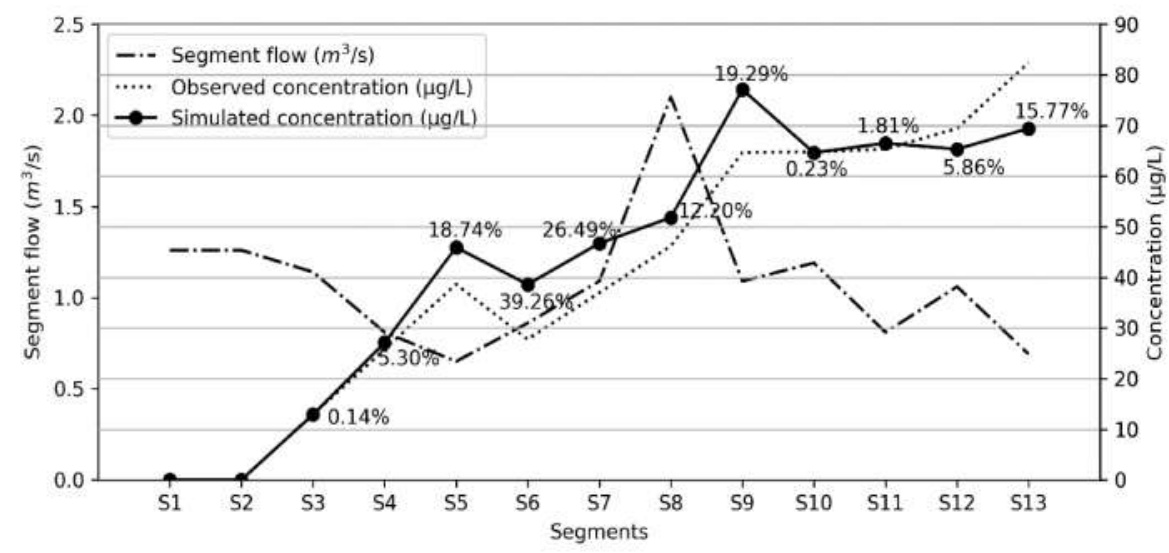

Figure $5 \mathrm{Cr}$ concentration, flowrate profiles and error percentages of $\mathrm{Cr}$ along the simulated stretch of Bogota River

situation is also evidenced in S-6, S-7 and S-8 for mixing condition.

S-9 presents a higher concentration at mixing conditions, near the initial concentration of the segment. This is presented because S-9 receives 2 discharges with $\mathrm{Cr}$ leading to an increase in the pollutant concentration. For S-10 and S-13, WASP did not achieve the stability condition, for this reason fluctuations of $\mathrm{Cr}$ concentration are represented by the model. We inferred that maximum dilution was not reached in the $24 \mathrm{~h}$ of running time for these sections (S-10 and 13).

Modification in the geometry of the river sections and flows of the discharge points were performed, variations in the $\mathrm{Cr}$ concentration were obtained for each segment. The advective mechanism is linked with the dispersion coefficient set in WASP with a value of $1 \mathrm{~m}^{2} / \mathrm{s}$. A modeling study developed in the Tumaque basin in Venezuela [14] supports this value based on the domination of the advective transport in the system. The coefficients obtained with the Fischer equation (Equation 3) have 


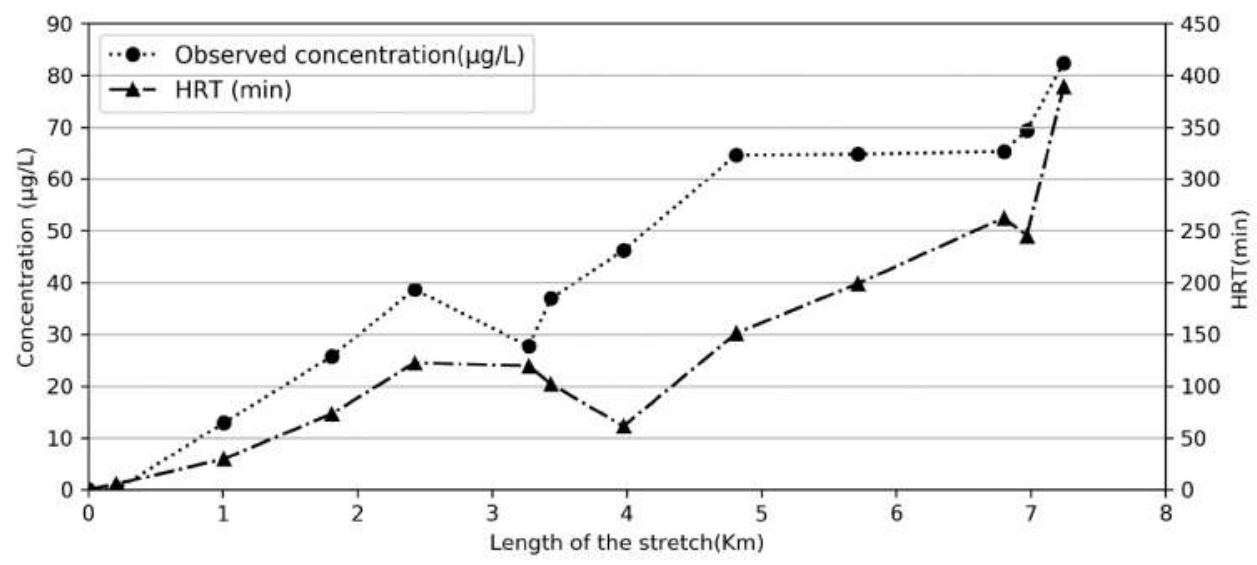

Figure 6 Profile of $\mathrm{Cr}$ concentration and HRT along the simulated stretch of Bogota River

dispersed values for the system analyzed in all the 13 segments. Due to this, the Peclet number (Equation 8) was computed, which makes it possible to identify accurately that the advective mechanism predominates in the transport of the contaminant $[21,22]$. Detailed data is available through the link in the supplementary material of this article.

Variations in the flow and the initial geometry of the segments allowed establishing the sensibility of the $\mathrm{Cr}$ concentration to the model configuration parameters. This observation can serve as qualitative validation of the model performance. From Figure 5, an increase in the flowrates, mainly associated with river section depth, corresponds to a decrease in the $\mathrm{Cr}$ concentration along the stretch of the river. These results are coherent with the equation of continuity (Equation 2).

Based on the obtained results (Figure 6), the hydraulic retention time (HRT) and the $\mathrm{Cr}$ concentration tend to increase along the stretch. 2 sections with local decrease were observed (S-6 and S-11), where pour Cr streams are added to the system. Profiles in Figure 6 allow observing the influence of the discharge flows and the geometry of the sections in HRT and concentrations. A clear relationship between concentration of $\mathrm{Cr}$ and HRT is also observed.

$\mathrm{Cr}$ concentration, along with segments from S-6 to S-8, was affected by the San Pedro stream. In contrast, concentration resulted higher along with segments from S-9 to S-11, which is explained by longer segment distances $(837,994 \mathrm{~m}$ to $1083,835 \mathrm{~m})$. An increase in the HRT affects $\mathrm{Cr}$ concentration because superficial absorption and sediment formation are favored, this behavior was reported in a previous work in the Bogotá river at Villapinzón sector where $\mathrm{Cr}$ traces were predominant in the sediment of the water stream
[23].

Similarly, a validation process to establish the accuracy and reliability of the simulation performed was implemented based in 2 quantitative indicators computed between observed and simulated results of $\mathrm{Cr}$ concentrations and water flowrates: the error and the IOA. The error in the whole stretch was computed as $2.6 \%$ average for the water flowrates (Table 4). For pollutant concentrations, the error percentage in the validation was $13,19 \%$ average. These error values are low indicating a good representation of the measured data by the proposed model.

The $50 \%$ of the granulometry that composed the bed of the simulated stretch from the river is $>2.7 \mathrm{~mm}$ [24], which indicates that infiltration can be avoided because evaporation or discharges are the main processes associated with loses in this system.

The error associated with the pollutant charge was higher in the segments S-6, S-7, and S-9 reaching values of $39,26 \%, 26,49 \%$, and $19,29 \%$, respectively (Figure 5). The difference between concentrations and flows in the segments are the main cause for the increase of the accuracy percentage in the second validation. Previous modeling studies made with QUAL2K [10] showed $\mathrm{NASH}$ coefficient in its calibration that ranges from 0.02 (insufficient) to 0.9 (excellent) [25], which confirms some sections present high accuracy and others some variation in the water stream.

Table $\mathbf{4}$ Involved flowrates in the validation

\begin{tabular}{ll}
\hline Segment or discharge point & Flow $\left(\mathrm{m}^{3} / \mathrm{s}\right)$ \\
\hline Input flow (S-1) & $1.26 \mathrm{~m}^{3} / \mathrm{s}$ \\
Flow sum & $1.23 \mathrm{~m}^{3} / \mathrm{s}$ \\
\hline
\end{tabular}

For the evaluation of WASP model performance, the 
IOA was computed as main validation parameter. The IOA value of 0.853 shown in was obtained from the simulated and observed concentrations of plotted in Figure 5. This IOA value indicates a high correspondence between observed and simulated data of $\mathrm{Cr}$ concentration in the water stream. This means WASP model implemented satisfies the criterion established by Willmont, reaching a greater value of 0.6 for this validation parameter [18]. IOA values were computed using OpenAir ${ }^{\circledR}$ Library in $\mathrm{R}$ programming language Figure 7.

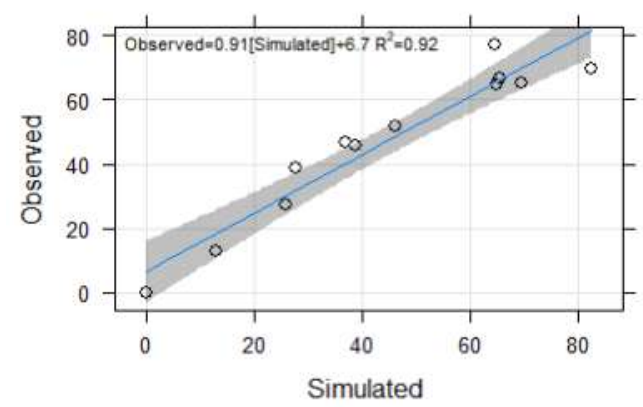

Figure 7 Scatter plot of simulated and observed pollutant concentration for validation, shadow with $95 \%$ of confidence

\section{Conclusions}

WASP model was implemented in this research to simulate the $\mathrm{Cr}$ concentration dispersion at the High Bogotá River Basin. Results with $13 \%$ average of error for the pollutant in the water stream were obtained. The segments S-6, S-7, and S-9 presented the highest error regarding the pollutant concentrations with error values of $39.26 \%$, $26.49 \%$, and $10.29 \%$, respectively. These error values are acceptable but can be improved for future studies by using highest spatial resolution and more simulated time. The model is capable to predict the hydraulic phenomena in the simulated river section with coherent results according to the dominating equations of the system. WASP model may get more accurate results by using hydraulic data from more accurate experimental methods and longer measuring campaign of the variables involved in the system. These experimental methods must be oriented to determine the geometry and water flow rates in the analysis system. The experimental method would get data capable to improve the WASP model prediction in terms of pollutant concentration error. Potential WASP model accuracy, also considering WASP model flexibility, make WASP to be a useful tool for the management of hydric resources based on mathematical and numerical modeling oriented to scenarios assessment.

The 13 segments used in this study present a gradual increase of the pollutant concentration of $\mathrm{Cr}$. These increments are observed upstream the mixing zone. The last 4 segments did not fully reach the mixing condition presented a $\mathrm{Cr}$ concentration of $70.48 \mu \mathrm{g} / \mathrm{L}$. This value corresponds to a high concentration since, in 2003, the $\mathrm{Cr}$ presence in surface water was between 1 and $10 \mu \mathrm{g} / \mathrm{L}$. This change puts in evidence a large impact by the industrial activity on the analyzed water system in this study during recent years.

The $\mathrm{Cr}$ III under high concentrations of organic matter can be oxidized to $\mathrm{Cr}$ VI [26], due to this feature $\mathrm{Cr}$ III can be taken as an indirect indicator of $\mathrm{Cr}$ VI a very harmful substance for human and animal health since it is a compound listed as a cancer promoter by WHO (World Health Organization). Environmental Control institutions in the region must develop sanitary regulations in the water system since currently, an optimum scenario for $\mathrm{Cr}$ oxidation is taking place in the river section. This situation is a potential risk and since $\mathrm{Cr}$ oxidation is mainly catalyzed by the organic matter heading to the river from sources such as residual domestic water and ledger industries residual water.

This study allowed validating the implementation of WASP model as a useful tool for the water resources modeling in Colombia and Latin America, due to the similarity in the hydric systems in the different Latin American countries, these systems are characterized by high mountains rivers or even lentic systems. WASP model versatility to perform different types of simulations with many variables allows the development of further important studies for water pollution. Considering the high rates of industrial increasing activities and water consumption in the region makes WASP has the potential to be important for future research, resources planning and development.

In this case, regarding the ledger production industry the model has significant opportunities to be implemented. The potential applications of the model cover use in the environmental assessment of polluted loads into the system and optimization of treatment processes for the industrial wastewater [26].

This research implemented a quantitative validation concluding WASP is capable of predicting accurately the behavior a system of water with polluted loads with an IOA of 0.853 between observed and simulated pollutant concentration [18]. The variables considered by the model as inputs and outputs can be used for assessment of impact in public health, sanity, and resource quality.

The modeling performed corresponds to a baseline which identifies errors and options of improvement oriented to a more accurate simulation in the future. This 
study is a starting point for related research in the topics of water resource quality assessment, scenarios analysis, and infrastructure development for decision-making processes in the region involving the effects of industry and local policies.

\section{Declaration of competing interest}

None declared under financial, profesional and personal competing interests.

\section{Acknowledgements}

Authors would like to thank by the data of the Bogotá river basin used in this document since it was provided by the Corporación Autonoma Regional (CAR). We also thank the Universidad Nacional Abierta y Distancia (UNAD) for allowing the development of research.

\section{Supplementary Material}

Table $\mathbf{5}$ Geolocation of segments, discharges and streams of the stretch of the river coordinates in UTM

\begin{tabular}{lll}
\hline Discharges & North & East \\
\hline D-1 & 575843.1 & 654786.6 \\
D-2 & 574926.7 & 654402.9 \\
D-3 & 574756.6 & 653975.4 \\
D-4 & 574122.7 & 653336.0 \\
D-5 & 574137.9 & 653213.0 \\
D-6 & 573697.5 & 652527.7 \\
D-7 & 573588.3 & 652155.5 \\
\hline Segment & North & East \\
\hline S-1 & 576000.8 & 654930.6 \\
S-2 & 575854.7 & 654798.8 \\
S-3 & 575218.4 & 654559.8 \\
S-4 & 574803.8 & 654123.5 \\
S-5 & 574703.3 & 653774.7 \\
S-6 & 574062.9 & 653437.6 \\
S-7 & 574116.7 & 653329.6 \\
S-8 & 573752.7 & 652559.2 \\
S-9 & 573713.8 & 651934.4 \\
S-10 & 573137.3 & 651580.3 \\
S-11 & 572563.7 & 651050.2 \\
S-12 & 572455.5 & 650925.3 \\
S-13 & 572232.4 & 650812.7 \\
\hline Streams & North & East \\
\hline T-16 & 574664.2 & 653726.7 \\
T-20 & 573073.4 & 651589.4 \\
\hline & & \\
\hline
\end{tabular}

Table 6 Available models for simulation of water systems quality

\begin{tabular}{|c|c|c|c|}
\hline Software & Advantages & Disadvantages & References \\
\hline QUAL 2K & $\begin{array}{l}\text { Useful for } \\
\text { simulation of } \\
\text { algal } \\
\text { concentration } \\
\text { and Biological } \\
\text { Oxygen Demand } \\
\text { in water. The } \\
\text { discretization } \\
\text { of segments } \\
\text { can be handled } \\
\text { irregularly. }\end{array}$ & $\begin{array}{l}\text { Specific } \\
\text { application for } \\
\text { users with defined } \\
\text { knowledge and } \\
\text { specific skills. } \\
\text { The model has } \\
\text { limitations in } \\
\text { simulation } \\
\text { parameters. } \\
\text { Heavy metals } \\
\text { cannot be } \\
\text { simulated. }\end{array}$ & {$[27]$} \\
\hline QUASAR & $\begin{array}{l}\text { Handling of } \\
\text { persistent } \\
\text { pollutants. }\end{array}$ & $\begin{array}{l}\text { The discretization } \\
\text { of segments is } \\
\text { limited and cannot } \\
\text { be handled } \\
\text { irregularly. It also } \\
\text { requires a lot of } \\
\text { experimental field } \\
\text { data. }\end{array}$ & {$[27]$} \\
\hline MIKE 11 & $\begin{array}{l}\text { Applied in the } \\
\text { evaluation of } \\
\text { water quality } \\
\text { in water bodies } \\
\text { affected by } \\
\text { dumping and } \\
\text { eutrophication. }\end{array}$ & $\begin{array}{l}\text { Several variables } \\
\text { associated with } \\
\text { heavy metals are } \\
\text { not available. } \\
\text { Detailed and not } \\
\text { available data } \\
\text { about the water } \\
\text { body are required. }\end{array}$ & {$[28]$} \\
\hline EFDC & $\begin{array}{l}\text { 3-D simulation } \\
\text { of hydraulic } \\
\text { data from } \\
\text { different water } \\
\text { bodies. EFDC } \\
\text { can be coupled } \\
\text { with other } \\
\text { model } \\
\text { systems. }\end{array}$ & $\begin{array}{l}\text { Simulation only } \\
\text { admits } \\
\text { hydrodynamic } \\
\text { transport for } \\
\text { pollutants. It lacks } \\
\text { graph interphase } \\
\text { as output. }\end{array}$ & [29] \\
\hline WASP & $\begin{array}{l}\text { 3-D simulation } \\
\text { for prediction } \\
\text { of affectation } \\
\text { in the water } \\
\text { quality for any } \\
\text { hydric system. } \\
\text { Previous } \\
\text { studies show } \\
\text { its application } \\
\text { in heavy } \\
\text { metals. It } \\
\text { offers 2-D } \\
\text { graph outputs. }\end{array}$ & $\begin{array}{l}\text { It requires } \\
\text { external sources } \\
\text { or previous results } \\
\text { for hydrodynamic } \\
\text { calculus. }\end{array}$ & [30] \\
\hline
\end{tabular}

\section{References}

[1] Elaboración del Diagnostico, Prospectiva y Formulación de la Cuenca Hidrográfica del río Bogotá Subcuenca río Alto Bogotá - 2120-19, 
Ecoforest Ltda., Bogotá, Colombia, 2006.

[2] C. Tobón, "Metabolismo social para el manejo sostenible de los recursos naturales. el agua en la cuenca Alta del Río Bogotá," M.S. thesis, Universidad Nacional de Colombia, Bogt ', Colombia, 2013.

[3] (2017) Índice de Calidad del Agua Tramo Cuenca Alta Río BogotáICATCA. Observatorio Regional Ambiental y de Desarrollo Sostenible del Río Bogotá. Accessed Oct. 10, 2018. [Online]. Available: https://bit.ly/2mqln 1 b

[4] G. Nordberg, Enciclopedia de salud y seguridad en el trabajo. Madrid, España: Ministerio de Trabajo y Asuntos Sociales, 1998.

[5] Presidencia de la Republica de Colombia. (1984, Jun. 26) Decreto 1594. [Online]. Available: https://bit.ly/2kN60Wn

[6] L. E. Amaya, D. E. Arriola, and Z. V. Cerna, "Modelación de la calidad fisicoquimica de las aguas del río Suquiapa," Undergraduate, Universidad de El Salvador, San Salvador, El Salvador, 2015.

[7] C. Matovelle, "Modelo matemático de calidad de agua aplicado en la microcuenca del río Tabacay," Killkana Técnica, vol. 1, no. 1, January 2017. [Online]. Available: https://doi.org/10.26871/killkana_tecnica. v1i1.19

[8] WASP8 Stream Transport-Model Theory and User's Guide, R. Ambrose, Atlanta, Giorgia, 2017

[9] A. M. Alvarez, J. M. Cuello, and A. E. Trento, "Transporte de sedimentos y metales pesados con WASP 7.0," Mecanica computacional, vol. XXV, no. 16, pp. 1425-1440, Nov. 2006.

[10] T. F. Santos, "Resumen ejecutivo, modelación de calidad de agua del río Bogotá y quebradas Chingacio y San Pedro con efluentes de curtiembre," M.S. thesis, Universidad Nacional de Colombia, Bogotá, Colombia, 2015.

[11] G. M. Barchiesi, F. Caminal, C. M. Garcia, H. Herrero, and J. M. Díaz, "Determinación del coeficiente de dispersión longitudinal en ríos usando ADCP," Revista Iberoamericana del Agua, pp. 26-37, 2015.

[12] J. Gracia and J. A. Maza, "Morfología de río," in Manual de Ingeniería de Ríos, J. Gracia, Ed. Mexico D.F.: Instituto de Ingeniería UNAM, 1997.

[13] J. Gracia and J. Maza, Manual de Ingeniería de Ríos. Mexico D.F.: Instituto de Ingeniería UNAM, 2002.

[14] R. Garcia, L. M. Marcó, G. Yacelli, G. G. Torres, and G. A. Yacelli, “Dispersión de contaminantes en cuenca Tumaque entre Lara y Yaracuy en Venezuela," Ingeniería Hidraulica y Ambiental, vol. 35, no. 2, pp. 79-93, 2014.

[15] Manual de buenas prácticas ambientales para la curtiembre en Centroamérica, U.S. EPA, Ciudad de México, 2006.

[16] J. L. Corredor, "El residuo líquido de las curtiembres estudio de caso: Cuenca Alta del Río Bogotá," Ciencia e Ingeniería Neogranadina, vol. 16, no. 2, pp. 14-28, Dec. 2006.

[17] L. A. Ramos, "Estudio de la dinámica del cromo en la cuenca alta del río Bogotá mediante la selección y aplicación de un modelo de calidad de agua para la representación de contaminantes conservativos en cuerpos de agua lóticos," Undergraduate, Universidad Nacional Abierta y a Distancia, Bogotá, Colombia, 2018.

[18] C. J. Willmont, S. M. Robeson, and K. Matsuura, "A refined index of model performance," International Journal Of Climatology, vol. 32, no. 13, November 15 2012. [Online]. Available: https: //doi.org/10.1002/joc.2419

[19] WASP7 Stream Transport - Model Theory and User's Guide, U.S. Environmental Protection Agency, Athens, Georgia, 2009.

[20] J. M. Sanz and A. Liñán, Integración geometrica, Nov. 2007.

[21] R. N. Petroni, “Desarrollo y aplicación de un modelo bidimensional de calidad del agua," Ingeniería Sanitaria y Ambiental, vol. 52, no. 1, pp. 34-44, Sep. 2000.

[22] M. L. Sámano, "Desarrollo e integración de modelos numéricos de calidad del agua en un sistema de información geográfica," Ph.D. dissertation, Universidad de Cantabria, Santander, España, 2011.

[23] L. F. Pinzón, E. A. Ospina, and A. Chávez, "Interacción de los metales pesados entre el sedimento y la columna de agua en el caso del río bogotá," Revista Gestión Integral en Ingeniería Neogranadina, vol. 1, no. 1, 2009.

[24] A. Navas, “Caracterización y modelación del transporte de sedimentos en la cuenca alta del río bogotá tramo - chingacio - puente santander," Undergraduate, Universidad de los Andes, Bogotá, Colombia, 2014.

[25] J. Cabrera, "Calibración de modelos hidrológicos," Undergraduate, Universidad Nacional de Ingeniería, Lima, Perú, 2012.

[26] L. Boutilier, R. Gordon, C. Lake, and R. Jamienson, “Modeling E.coli fate and transport in treatment wetlands using the water quality analysis and simulation program," Journal of Environmental Science and Health Part A, vol. 46, no. 7, 2011. [Online]. Available: https://doi.org/10.1080/10934529.2011.571576

[27] B. E. Diaz, "Modelación de la calidad del agua en el interceptor río Bogotá en los tramos Fucha - Tunjuelo - Canoas," M.S. thesis, Universidad de los Andes, Bogotá, Colombia, 2004.

[28] Modelización de recursos hídricos, DHI Water and Environment, Peru, 2002.

[29] Análisis de herramientas de evaluación de la difusión y comportamiento de agentes quimicos en el marco de la normativa de responsabilidad ambiental, Ministerio de Medio Ambiente y Medio Rural y Marino, Madrid, España, 2011

[30] C. Cardona, "Desarrollo de un modelo espacio-temporal de la hidrodinámica y la temperatura de un cauce fluvial : caso de estudio río Fucha," M.S. thesis, Pontifica Universidad Javeriana, Bogotá, Colombia, 2009

[31] (2019) Consolidado de datos. Accessed Apr. 20, 2020. [Online]. Available: https://bit.ly/3avlygp 